\title{
The case of adolescents and young people who autonomously engage in selling sex in latin america and the caribbean: recognizing their sexual and reproductive health needs and demands
}

\begin{abstract}
Background: "Sex work is an issue that has raised debate in the academic, political, and civil society fields as well as in the media, due largely to political and ideological content that is poured into the exercise of sexuality". ${ }^{1}$ When we talk about adolescents and young people engaged in selling sex, it's common to automatically imagine the victims of human trafficking and sexual exploitation. However, those working around HIV, recognise that, in contrast to that scenario, there are some people who, due to precarious economic conditions, choose to engage in selling sex, even before the age of 18. It is needed to have clear that "sex work contrasts with the other terms as its categorisation as work is linked to the fact that it is carried out with the full consent of the person who exercises it". ${ }^{2}$
\end{abstract}

Methods: Qualitative research conducted in 2015-2016, using a non-probabilistic sample (snowball) reaching 99 individuals (31 young women, 36 young trans women, and 32 young men), participating in different focus groups in Brazil, Colombia, Honduras and Dominican Republic. Scientific literature and policy documents were reviewed. The narrative analysis was made through qualitative coding and categorisation.

Results: Young people who autonomously engage in selling sex in Latin America and the Caribbean perceive themselves at risk for HIV, other ITS's, or unplanned pregnancies and usually are target of stigma, discrimination and violence by their clients and police. Moreover, the risk is perceived to increase when clients ask them to use drugs, an issue that happens even when they have let the clients know in advance that they do not use drugs. After their refusal to use drugs, sometimes they are hit and forced to use them.

Conclusion: While it is true that countries have an obligation to ensure the protection of young people who have been victims of human trafficking and commercial sexual exploitation, they also should have adequate health regulations so that those who choose to sell sex, including minors, have access to health services, particularly sexua and reproductive healths services and specially in HIV and other ITS

Keywords: Youth, autonomy, engage in selling sex, latin america and the Caribbean, sexual and reproductive Health, HIV \& aids
Research Article

Volume 7 Issue 2 - 2018

\section{Corral Miguel}

National Autonomous University of Mexico, Mexico

Correspondence: Corral Miguel, National Autonomous University of Mexico, Postgraduate Program of Latin-American Studies, México City, México, Tel +52 I (664) I88 7859,

Email: miguel.corral.estrada@gmail.com

Received: December 14, 2017 | Published: March 06, 2018

\begin{abstract}
Abbreviations: Aids, acquisition immunodeficiency syndrome; CTA, centers for testing and counseling; HIV, human immunodeficiency virus; ILO, international labour organisation; LGBTI, lesbian, gay, bisexual, trans, intersex; MSM, men who have sex with other men; PSU, emergency care units; RedTraSex, network of sex workers in latin america and the caribbean; STI, sexually transmitted disease; trans, transgender, transexual, transvestites; UNAIDS, joint united nations programme on HIV and AIDS
\end{abstract}

\section{Introduction}

Sex work is a global phenomenon and in most countries it is considered an illicit activity, causing those who practice it to do so in clandestinity. This circumstance increases the conditions of vulnerability of people engaged in selling sex. It is common for sex workers to experience precarious conditions, in the realms of labour and education. ${ }^{3}$ For many of them, getting engaged in selling sex is worth than other types of jobs, such as housekeeping, babysitting or working in factories. Sometimes, migration may be another factor related with sex work. On the other hand, given that in most cases HIV is sexually transmitted, sex work represents a high risk for those who perform it due to the number of sexual contacts they have. ${ }^{3}$ The risk of HIV and other STI's infections increase among younger people. ${ }^{4}$

"Sex work is an issue that has raised debate in the academic, political, and civil society fields as well as in the media, due largely to political and ideological content that is poured into the exercise of sexuality". ${ }^{1}$ It is needed to have clear that "sex work contrasts with the other terms as its categorisation as work is linked to the fact that it is carried out with the full consent of the person who exercises it". ${ }^{2}$ 
When we talk about adolescents and young people engaged in selling sex, it's common to automatically imagine the victims of human trafficking and sexual exploitation. However, those involved in the prevention, detection, care and treatment of HIV, recognise that, in contrast to that scenario, there are some people who, due to precarious economic conditions, choose to engage in selling sex, even before the age of 18 . The complexity of this issue requires us to understand the phenomenon before us. While it is true that countries have an obligation to ensure the protection of young people who have been victims of human trafficking and commercial sexual exploitation, they also should have adequate health regulations so that those who choose to sell sex, including minors, have access to health services, particularly sexual and reproductive healths services.

A big concern is that not one of the countries in the region has comprehensive laws on sex work. The lack of legislation on the issue means constant submission to the interpretation and arbitrary discretion of different social actors who often violate their rights: police, educators, health service providers, among many others. ${ }^{6}$ Others studies had been developed around young people who autonomously engaged in selling sex in other regions of the world,, 4 but this is the first time that a study of this kind is made in Latin American and the Caribbean, without positioning this population in the realm of children sexual exploitation. Due to this question, the aim of this investigation was to achieve a greater understanding of the needs and problems faced by adolescentes and young people under-18-engaged in selling sex in Latin American and the Caribbean, particularly needs and problems related to sexual and reproductive health services, access, with a special focus on HIV. A human rights and gender perspective led the entire process, due the importance on this issue expressed by UNAIDS. ${ }^{8}$

This research was developed in three phases: A) Reviewing the available literature on the subject in the region, especially policies and regulations; B) Conducing focus groups in Brazil, Colombia, Honduras, and the Dominican Republic were conducted with young men, young women, and trans youth engaged in selling sex; C) A consultation with youth representatives engaged in selling sex from various countries and representatives of different key populations. Finally, we present the findings and next steps, regarding what needs to be done in order to improve the living conditions of the young people who autonomously engage in selling sex in Latin America and the Caribbean.

\section{Materials and methods}

For a comprehensive understanding of this phenomenon in the region, various different sources were used.

i. Revision of scientific literature and international guidelines related to six main themes: Law and the human rights, ${ }^{8-10}$ sexual and reproductive health and rights, ${ }^{8,11-16}$ youth development, ${ }^{17,18,19,15,20,21} \mathrm{HIV}^{8,22-28}$ commercial sexual exploitation of children, ${ }^{29-33}$ and sex work. ${ }^{34-44,2,45-53}$ This exercise allowed us to gain a perspective about how this problematics are lived in the everyday life of people engaged in selling sex, the juridical situation of sex work in each country of the region, and to establish the ground to formulate the guides for the focus groups. There was special interest in the gaps between the national panorama and the recommendations made by international agencies ii. Reaching out the population and the conformation of focus groups. Because the stigmatization of young people engaged in selling sex in Latin America and the Caribbean is still a great problem for this population and therefore they are difficult to reach, it was decided to conform a non-probabilistic sampling using the snowball technic. ${ }^{54}$ To that end, we contacted civilsociety organisations with community-based work to access participants. Overall, 99 individuals participated in the focus groups. ${ }^{55}$ At the time of contact, $66 \%$ of participants were aged 21 $25,25 \%$ were $19-24$, and $9 \%$ were $14-18$ years old. Nonetheless, all of them engaged in selling sex under the age of 18 . While this number is not intendedto be representative of the population of young people engaged in selling sex in Latin Americaand the Caribbean, it allows us learn about therealities they live every day. Twelve focus groups were conduced, three in each country. In each of the focus groups there were four themes discussed: access to sexual and reproductive health, with an emphasis on HIV; other health services; information and education; and, other issues, primarilyissues of stigma, discrimination and violence. At the beginning of each focus group, the purpose of the investigation was explained, indications were given and they were asked to sign a letter of voluntary consent and confidentiality. Speech recorders were used and the information was transcribed into a database, using the categorization initially established. The analysis was made in the base of codification, ${ }^{56}$ exploring the essence of data, develop conceptual elements and establish relationships between them (Table 1). ${ }^{57}$

iii. Regional consultation on young people who autonomously engage in selling sex. Lastly, we conduced a regional consultation with young people engaged in selling sex in Bogotá, Colombia. The event included the participation of 15young people from Argentina, Brazil, Colombia, Costa Rica, Dominican Republic, Guatemala, Mexico, Panama, and Paraguay. The purpose of the meeting was to connect young people from different countries, in a space where they could dialogue, discuss, organise, and propose courses of action. The aim of this consultation was to contrast our findings with the perspective of research external none-participants young people engaged in selling sex. Their thoughts and comments about our results, helped us to have a more clear perception about their situation in Latin America and the Caribbean. The most important outcome of this process were the recommendations made to be presented before stakeholders in the region. This component represent a linkage between the production of scientific knowledge and the potential social and political impact of this investigation.

Table I Number of participants in each country

\begin{tabular}{llllll}
\hline & Brazil & Colombia & $\begin{array}{l}\text { Dominic } \\
\text { Republic }\end{array}$ & Honduras & $\begin{array}{l}\text { Total } \\
\text { per } \\
\text { group }\end{array}$ \\
\hline Women & 7 & 7 & 10 & 7 & 31 \\
Trans & 8 & 10 & 11 & 7 & 36 \\
MSM & 6 & 11 & 8 & 7 & 32 \\
Total & 21 & 28 & 29 & 21 & 99 \\
\hline
\end{tabular}

\section{Results and discussion}

Several findings were made among this three populations. Due the interest is to show an overview of the region, we group the most 
relevant results from the common situations that were reported in the four countries, by young women, young MSM and young trans women, who autonomously engaged in selling sex. In general, they perceive themselves at risk for HIV, other sexually transmitted infections, or unplanned pregnancies, in the case of young women. These latter mentioned that there is no difference between engaging in selling sex on the street versus in a private or public establishment (brothels, hotels), since it is not always possible to identify whether clients are violent individuals or not. A shared mayor concern for the three populations is that, moreover, the risk is perceived to increase when clients ask them to use drugs, an issue that happens even when they have let the clients know in advance that they do not use them. After their refusal to use drugs, sometimes they are hit and forced to use them. Another frequent situation is that they are request to have condomless sex. Particularly in the case of young MSM and trans women, they commented that due to the economic precariousness in which they find themselves and that is the main reason for which they decided to engaged in selling sex since the beginning, they accept if more money is offered. This even when they recognize the harmful consequences it can have on their health. Three most common justifications that clients use to justify not using a condom are: they cannot maintain an erection, they take longer to ejaculate, and condoms provoke allergic reactions.

Stigma and discrimination are a common place among young people who autonomously engaged in selling sex, consequently they prefer not to be associated with engaging in selling sex for fear of being recognised, or deny it. For young MSM, the principal reason is that some of them have a girlfriend or wife. Specifically in healthcare centers, young women believe that because they are considered "infectious agents", they are not well-received and sometimes healthcare providers injure them during vaginal examinations. In the case of young trans women, it is essential that healthcare providers are trained on gender and sexual identity, as it is common that they are referred to in masculine. Young MSM and young trans women referred that when identifying symptoms of an infection, they prefer self-treatment before resorting to health centres because they fear discrimination. Another form of self-medication among young trans women is the use of hormone treatments (usually without professional supervision) or other treatments that are unsafe to feminise their bodies. These include: oil injection or injection other substances, or silicone implants. Often these treatments can endanger their lives. Likewise, the lack of confidentiality is usually identified as a common problem among the three populations, which also limits their access to health centers, in addition to the fact that they believe that the services offered to them are deficient, and that they are not sensitive to the needs of the youngest. Thus, none of the three populations trust the police. Their experience with the police is negative and they do not trust the justice system. When arrested, they can be forced to have sex (mostly without a condom) as a blackmail to release them. Lastly, The lack of access to prevention supplies is another situation for those who are older, because in health centers they often refuse to give condoms because of their age, at least they assist with an adult.

\section{Conclusion}

In Latin America and the Caribbean as well as in other regions of the world, exist individuals that autonomously decide to engage in selling sex even before they are 18 years old, mostly due the precarious economic conditions. These individuals have the capacity to understand the activity they are engaging in and should not be confused with sexual children exploitation. Hence, it is important that HIV programs and organisations working in this field implement educational and preventive strategies with them in order to decrease the rates of HIV and other STI's among these populations, and this interventions must integrate a stigma and discrimination component based on the human rights approach. While they can benefit from HIV prevention, testing and treatment and care programs aimed at adult sex workers, the youngest people have particular needs and should be taken into account as such: they do not feel comfortable when health centres require that they be accompanied by an adult in order to receive services because they feel that this practice does not guarantee confidentiality; although they are minors, it is important to have access to preventive resources and are not turned away. Generally they need laws that protect them and consider them subjects of rights, without victimizing them.

There is also an urgent demand for health-service providers who have the necessary elements to provide services for them, without discrimination. They should be trained on how to care for adolescents and young people who autonomously engage in selling sex and the LGBT community. They believe that if they did not receive negative treatment by providers of sexual and reproductive health, it is likely that they will access services and prevention methods. There is an existing urgent need to sensitize and raise awareness among police personnel, because the perceived risk of being arrested could conduce these populations to engaged in more clandestine conditions that put them in mayor risk for acquisition of HIV and other ITS's.

\section{Acknowledgement}

Our most sincere and heartfelt thanks go first to each and every one of the young people who decided to go on this journey with us and who, on the way, shared their experiences, their emotions, and their ways of thinking about being engaged in selling sex. Without a doubt, the most valuable contribution is theirs and without them none of this would have been possible. We also want to let them know they are not alone and that their struggle is shared by the research team.

\section{Conflict of interest}

This work shows the results of the investigation "Health Equity for All", financed by the Stepping Stones of Aids Fonds, with the support of HYLF, an organisation of and for young people that provides technical and financial support to projects led by young people affected by HIV.

\section{References}

1. Bonilla RM, Campos RR, Suárez eIR. Patriarcado y trabajo sexual en el imaginario social de la Costa Rica del siglo XXI. La Ventana. 2013;38:122-163.

2. Acero TM. El debate entre prostitución y trabajo sexual. Una mirada desde lo socio-jurídico y la política pública. Revista de Relaciones Internacionales. 2011;6:127-148.

3. United Nations Programme on HIV/AIDS. UNAIDS Guidance Note on HIV and Sex Work. Geneva. 2009.

4. Conner B, Mago A, Middleton-Lee S. Sexual and reproductive health needs and access to health services for adolescents under 18 engaged in selling sex in Asia Pacific. HIV Young Leaders Fund. Amsterdam. 2014.

5. United Nations International Children's Emergency Fund. Fact Sheet About Child Protection. Commercial Sexual Exploitation. New York. 2016 . 
6. Latin American and Caribbean Women Sex Workers' Network. Study on Working Conditions for Sex Work in 14 countries in Latin America and the Caribbean. Buenos Aires. 2016.

7. World Health Organization. HIV and young people who sell sex. Technical brief. WHO Press. Geneva. 2015.

8. United Nations Programme on HIV/AIDS. How Aids Changed Everything MDG 6:15 years, 15lessons of hope from the aids response, Geneva, 2015.

9. Cavagnaro MV, Colazo II. Las niñas, niños y adolescentes como sujetos de derecho frente a la figura del usufructo paterno-materno: Una mirada a partir del interés superior del niño y de la capacidad progresiva: Su abordaje desde la legislación vigente y proyecto de reforma de Código Civil y Comercial de la República Argentina. 2013

10. United Nations Population Fund, World Health Organization, United Nations Programme on HIV/AIDS, FHI360 (2012) Preservativos femeninos: Especificaciones generales, pre-calificación y directrices de adquisición. WHO New York/Geneva.

11. United Nations Economic Commission for Latin American and the Caribbean. Integración plena de la población y su dinámica en el desarrollo sostenible con igualdad y enfoque de derechos: clave para el Programa de Acción de El Cairo después de 2014. Reported presented at the First Meeting of the Regional Conference on Population and Development in Latin America and the Caribbean. Montevideo. 2013.

12. United Nations Economic Commission for Latin American and the Caribbean. Plan de Acción Regional Latinoamericana y del Caribe sobre Población y Desarrollo. Report presented at the Regional Latin American and the Caribbean Plan of Action on Population and Development. Santiago de Chile. 1996

13. Hunt F. Evaluación de la implementación de la Declaración Ministerial "Prevenir con Educación 2012" Del acuerdo a la acción; Avances en Latinoamérica y el Caribe. IPPF. Mexico City. 2013.

14. Secretaría de Salud. Declaración Ministerial "Prevenir con Educación". report presented at the First Meeting of Ministers of Health and Education to Stop HIV in America Latina and the Caribbean. México City. 2008.

15. Contreras JM, Hakkert R. La sexualidad y la formación de Uniones. Diagnóstico sobre salud sexual y reproductiva de adolescentes en América Latina y el Caribe. UNFPA. Mexico City. 2001.

16. United Nations Population Fund. Report from the International Conference on Population and Development. Cairo. 1994.

17. Pan-American Health Organization. Manual de actividades para la reducción de estigma y discriminación relacionados a ITS, VIH y Sida. PAHO. Washington, D. C. 2013

18. United Nations Children's Emergency Fund. Estado mundial de la infancia 2011. La adolescencia, unan época de oportunidades. UNICEF. New York. 2011.

19. United Nations Programme on HIV/AIDS. Informe Mundial. Informe sobre la epidemia mundial del Sida. UNAIDS. Geneva. 2009

20. Ibero-American Youth Organization. Convención Iberoamericana de derechos de los jóvenes. 2005.

21. World Health Organization. La salud de los jóvenes: un desafío para la sociedad. Report presented at the WHO study group about young people and "Health for All by the year 2000". Geneva. 1986.

22. United Nations Programme on HIV/AIDS. Fas-track. Ending the Aids epidemic by 2030 . UNAIDS. Geneva. 2014

23. United Nations Programme on HIV/AIDS. People living with HIV UNAIDS. Geneva. 2014.

24. United Nations Programme on HIV/AIDS. Orientaciones terminológicas de ONUSIDA. UNAIDS. Geneva. 2014
25. United Nations Programme on HIV/AIDS. handbook on HIV and Human Rights. UNAIDS/UNHCHR. Geneva. 2014.

26. Pan-American Health Organization. Salud sexual y reproductiva al alcance de los adolescentes pobres y en situación de vulnerabilidad. PAHO. Washington, D. C. 2013.

27. United Nations General Assembly on HIV/Aids. Declaración Política sobre el VIH/Sida: intensificación de nuestro esfuerzo por eliminar el VIH/ Sida. New York City. 2011

28. Centurión M, Duranti R, Hessling M, et al. Salud, VIH-Sida y sexualidad trans. Buenos Aires.

29. United Stated Department of State. Trafficking in personas report. 2015.

30. Global Network of Sex Work Projects. Sex Work is Not Trafficking Summary. 2011

31. United Nations Office on Drugs and Crime. 2009

32. Global report on trafficking in personas. Human Trafficking, a crime that shames us all. UNODC. New York City.

33. International Labour Office Guidelines on the design of direct action strategies to combat commercial sexual exploitation of children. ILO. Geneva. 2007.

34. Arroyo L, Amador K. Turismo y trabajo sexual en Cancún-México. Estudios y perspectivas en turismo. 2015;24:982-992.

35. Mendieta G, Ramírez JC, Pérez E. Prostitución masculina: una revisión narrativa. Andina. 2015;(17)31:1368-1389.

36. Pecheny M. Estigma y discriminación en los servicios de salud a las mujeres trabajadoras sexuales en América Latina y el Caribe. Gaceta de Antropología. 2014;30(3)

37. Morales R, Rojas R, Ramírez I. Patriarcado y trabajo sexual en el imaginario social de la Costa Rica del siglo XXI. La Ventana. 2013;(38):122-163.

38. Mercedes I, Caballero S, Carrera L, et. al. Factores asociados a síntomas depresivos en trabajadoras sexuales. Anales de la Facultad de Medicina. 2010;(7)4:277-282.

39. Britos $\mathrm{P}$ ¿Por qué la prostitución debe ser un trabajo sexual?. A parte Rei. 2009;66:1-12.

40. United Nations Programme on HIV/AIDS. Notas de orientación ONUSIDA sobre VIH y el trabajo sexual. UNAIDS. Geneva. 2009.

41. Córdova R. Identidades sexuales y prácticas corporales entre los trabajadores sexuales de las ciudades de Xalapa y Veracruz. Nueva Antropología, 2008;(21)69:83-103.

42. Juliano D. El trabajo sexual en la mira. Polémicas y estereotipos. Cadernus Pagu 2005;(25):79-106.

43. Amaya A, Canaval G, Viáfara E. Estigmatización de las trabajadoras sexuales: influencias en la salud. Colombia Médica. 2005;36(3):65-74.

44. Dorais M. Intimidad en venta: ¿Cómo se llega a ser trabajador sexual? Descartos. 2004;(16):52-68.

45. Rodríguez EM, Fuentes P, Ramos-Lira 1, et al. Violencia en el entorno laboral del trabajo sexual y consumo de sustancias en mujeres mexicanas. Salud Mental. 2014;(37)4:355-360.

46. Valencia NN, Cataño GY, Fadul AK. Percepción de riesgo frente a las infecciones de transmisión sexual de trabajadoras sexuales de algunos establecimientos de Monterira-Córdoba (Colombia). Investigación y Desarrollo. 2011;(19)1:64-87.

47. Theodore F, Gutiérrez JP, Torres P, et al. El sexo recompensado: una práctica en el centro de las vulnerabilidades (STI/VIH/Sida) de las jóvenes mexicanas. Salud Pública de México, 2004;(46)2:104-112. 
48. Allen B, Cruz-Valdez A, Rivera L, et al. Afecto, besos y condones: el $\mathrm{ABC}$ de las prácticas sexuales de las trabajadoras sexuales de la Ciudad de México. Salud Pública de México. 2003;5(45):594-607.

49. Overs C, Longo P. Haciendo el trabajo sexual seguro. Cordoba National University. Argentina. 2002.

50. Aragón J. Variables cognitivo conductuales y VIH en trabajadoras sexuales de la frontera de Venezuela y Colombia. Aldea Mundo. 2000;5(9):5-19.

51. Lamas M. Trabajadoras sexuales: del estigma a la conciencia política. Estudios Sociológicos. 1996;(14)40:33-52.

52. Tirado M. El trabajo sexual desde una perspectiva de los derechos humanos: implicaciones del VIH/Sida e Infecciones de Transmisión Sexual. Civilizar: Ciencias Sociales y Humanas. Bogotá. 2014;27(14): 97-110.

53. Latin American and Caribbean Women Sex Workers' Network. Study on Stigma and Discrimination among Healthcare services for women sex workers in Latin America and the Caribbean. Buenos Aires. 2013.
54. Martínez-Salgado C. Sampling in qualitative research. Basic principles and some controversies. Brasil. Ciência \& Saúde Coletiva. 2012;17(3):613619.

55. de Gialdino V, Ameigeiras AR, Chernobilsky, et al. Estrategias de investigación cualitativa, Barcelona, Editorial Gedisa, p. 175-212.

56. Andréu Abela J, García-Nieto A, Pérez Corbacho, et al. Evolución de la teoríafundamentada como técnica de análisis cualitativo. Cuadernos Metodológicos. Centro de Investigaciones Sociológicas CIS. Madrid. 2007;(40):208.

57. Schettini P, Cortazzo I. Análisis de datos cualitativos en la investigación social: procedimientos y herramientas para la interpretación de información cualitativa. Editorial de la Universidad de La Plata. Buenos Aires. 2015. 